\title{
The Global Education Programme in the Era of the Knowledge Based Economy: Context and Implications
}

\author{
M. KOVALENKO*
}

\begin{abstract}
*Marina Kovalenko-Senior Lecturer in English, Department of English for the Humanities, National Research University Higher School of Economics. Address: 3, Bolshoj Trekhsvyatitel'skij lane, Moscow, 123022, Russian Federation. E-mail: mkovalenko@hse.ru

Citation: Kovalenko M. (2017) The Global Education Programme in the Era of the Knowledge Based Economy: Context and Implications. Mir Rossii, vol. 26, no 3, pp. 117-141. DOI: $10.17323 / 1811-038 X-2017-26-3-117-141$
\end{abstract}

The Global Education Programme (GEP) is an innovative government funded programme that offers Russian citizens the opportunity to study full-time at leading foreign higher education institutions and requires them to get employment in Russia in accordance with the qualification gained for a minimum of three years. Its purpose is to introduce the best international experiences and to apply them in Russia. Both the humanistic aims of GEP to provide access, equity, and social justice to high academic achievers and the number of obstacles to the long-term goals of modernization are core elements of this discussion. "5-100-2020", an umbrella programme focused on both internal and international development, is discussed. Striving for better positions in top world rankings is viewed from a wide range of perspectives. The article assesses the extent to which GEP fits with the concepts and theories of internationalization, explores GEP as a policy initiative for economic modernization, and identifies the main mismatches between the ambitions and challenges of GEP. The political and cultural contexts are taken into consideration and intercultural comparisons are made. GEP participant survey data and their views on the programme reflecting their professional experiences are analysed.

The first steps of GEP including grant awards to 718 GEP participants were not fully implemented. According to 8 December 2016 data, the number of participants was 413 which is less than 58\% of the planned number. The funding process has been officially prolonged until 2025. The completion of GEP will be officially announced only after the fulfilment of the employment commitments by all the participants who have successfully completed their studies abroad.

Key words: GEP, knowledge-based economy, internationalization, educational policy initiative, political context, cultural context 


\section{The Global Education Programme: potential and challenges}

The Global Education Programme (GEP) is an innovative government funding programme that offers Russian citizens an opportunity to study full-time at leading foreign higher education institutions and requires them to get employment in Russia in accordance with the qualification gained for a minimum of three years. The programme aims to increase the number of highly-qualified personnel in science, education, engineering, medicine and management in the social sphere according to Russian economic priorities [Ukaz prezidenta Rossijskoj Federatsii 2013]. The programme cooperates with leading Russian employers, including those registered in the territories of advancing socioeconomic development in the Far East and Eastern Siberia in order to speed up the modernization process and introduce new technologies for social reform. The binary nature of GEP targets is drawn from the fact that GEP is a measurement for human resource empowerment and a social support programme at the same time.

Although the humanistic aims of the programme to provide access, equity, and social justice to students with high academic achievement and guarantee significant financial incentives to them appear to be fair and explicit, there are areas of concern:

- an unexpected lack of competition between applicants

- the relatively low reach of the advertising campaign

- difficulties with the funding process due to exchange rate fluctuations

- a mismatch between the international curriculum and future work responsibilities

- an incongruence between the demand for work in industrial and educational centres (Moscow and Saint-Petersburg) and the elimination of this possibility at the initial stages of the employment process

- the potential risks of a "brain drain" depending on future economy (in)stability

The diversification and decentralization of the Russian economy are long-term strategies and the educational experiences of GEP participants are of significant importance in this regard. This article captures the intermediate outcomes and analyses the issues and implications shaping the programme from inside, its dynamics and areas for improvement.

\section{Internationalization and its implications for higher education worldwide}

Recent decades have seen a considerable increase in the volume of international students worldwide. Their number saw a five-fold increase from 0.8 million in 1975 to 4.1 million in 2010 [Quarterly National Accounts 2012]. This is a global phenomenon integrating higher education into other areas of economy: "The internationalisation of higher education has moved from the fringe of institutional interest, such as student exchange programs, to the core initiatives, for example, the big business of recruitment and academic collaboration over the past two decades" [Brandenburg, De Wit 2011, cited in Jiang, Carpenter 2014, p. 56].

The concept of internationalization has been interpreted on different levels by various researchers. Knight's article emphasizes its loose definition and its position under the umbrella term of globalization. The development of advanced communication and technological services, increased international labour mobility, an emphasis on the market economy and trade liberalization, a focus on the knowledge society, increased 
levels of private investment, decreased public support for education, and lifelong learning are highlighted as the key drivers of change [Knight 2004, p. 7].

Prioritizing some points and underemphasizing others, the concept of internationalization includes [Knight 2004, p. 6]:

- a series of international activities (academic mobility for students and teachers)

- international links

- partnerships and projects

- new international academic programs and research initiatives

- the delivery of education to other countries through new types of arrangements (branch campuses or franchises using a variety of face-to-face and distance techniques)

- the inclusion of an international, intercultural, and/or global dimension into the curriculum and the teaching and learning process

- international development projects

- the increasing emphasis on trade in higher education.

In 2009 the Council of the European Union placed academic mobility at the top of its strategic objectives for education. Academic mobility is represented as "an essential element of lifelong learning and an important means of enhancing people's employability and adaptability" [Council Conclusions of 12th May 2009, p. 3, cited in Robertson 2010, pp. 671-672]. However, there is criticism for using this concept "as a proxy for internationalization, excellence and competitiveness" as it is only "one means of achieving international research collaboration and knowledge transfer" [Ackers 2008, p. 432] emphasizing the fact that "individual mobility experiences vary considerably and are not always a marker of academic excellence transfer" [Ackers 2008, p. 413]. Mobility may not fully fit the recognized ideas of internationalization on a qualitative level as it is shaped by a number of chaotic forces.

Academic mobility has a strong correlation with "brain drain", the interpretation of which is dependent on stakeholder motivations and the legal mechanisms restricting it. Robertson suggests "turn[ing] brain drain into other possibilities, such as 'gain' and 'circulation' through movements back and forth via remittances, networks, and other forms of knowledge exchange" [Robertson 2010, p. 643] and emphasizes some economic agency in student and staff mobility. This perspective is shared by other researchers who highlight that international students "are likely to establish transnational linkages and act as multipliers of international relations in their subsequent careers" [Saxenian 2006, as cited in Jöns, Hoyler, 2013, p. 56].

Jöns \& Hoyler also point out that recent work on the formation of global educational/ knowledge hubs in the world economy has emphasized the new role of universities as both outcomes and drivers of globalization and positioning the geographies of world university rankings within wider socio-economic processes [Jöns, Hoyler 2013]. Robertson \& Olds say that "rankings have unleashed a battle for brains, and lifted to even greater prominence and importance the role of the university in advancing globallycompetitive knowledge-based economies" [Robertson, Olds 2012, p. 3]. However, Madge et. al. draw attention to the fact that many places and people are marginal or absent from global higher education as "international study is bound up tightly with questions about (in)equality, 'aspiration' and 'development"' [Madge, Raghuram, Noxolo 2014, p. 695]. Jöns \& Hoyler contrast quantity and quality citing the example of the highly uneven geographies of higher education which restrict the global circulation of knowledge and 
expertise, "Anglo-American publication cultures in the highly expensive technosciences that facilitated American hegemony in the second half of the 20th century and are seen as drivers of economic growth" [Kenway, Bullen, Robb 2004; Paasi 2005, as cited in Jöns, Hoyler 2013, p. 56]. However, they predict that "expected international student flows will be able to reinforce the central status of some of the existing global knowledge hubs and to contribute to the formation of new central nodes in the world economy" [Jöns, Hoyler 2013, p. 57], in Asia Pacific and China in particular.

The current phenomenon of non-stop competition is a practical example of the concepts explored in "The Ethics of Internationalization in Higher Education: Hospitality, self-presence and "being late": "There is no experience of internationalization that is not at the same time singular and repeated. Repeatability bears 'the trace' not only of what has happened - and we seem 'late' for it because it has already disappearedbut also the possibility of what is about to come and what is not as yet present. Every experience of internationalization is thus never quite on time: time is 'anachronism"" [Derrida 2000, p. 20, cited in Hughes-Warrington 2012, p. 319].

Knight asks a number of rhetorical questions about further internationalization outcomes, contrasting cultural diversity in the curriculum, the teaching and learning process, research, extracurricular activities, the contribution of academic mobility to intercultural understanding with cultural homogenization threatening to devaluate minor culture representations and the loss of the multiple dimensions of numerous world cultures [Knight 2004, p. 29].

Extremes of development and the limitless growth of connections may look very optimistic, but could jeopardize the promising outcomes of international education especially regarding the issue of vulnerable cultures. Understanding versus dominance, and diversity and coexistence versus homogenization require careful treatment and protection from manipulation by economic forces.

\section{GEP as a policy initiative: striving for a knowledge-based economy}

As pointed out in the OECD report, measuring knowledge and forecasting its impact on the economy is a complex challenge as it depends on "entrepreneurship, competition and other economic circumstances" [The Knowledge-Based Economy 1996, p. 26]. The qualitative and innovative nature of knowledge which "provides product and process options that were previously unavailable" [The Knowledge-Based Economy 1996, p. 30] is specified. However, tracing the use of knowledge and its further benefits, and conducting scientific investigations on its direct applicability to technological innovation are not seen as exclusively accountable and unambiguous processes; knowledge has a huge potential to "save resources that would otherwise be spent" [The Knowledge-Based Economy 1996, p. 26]. As a result the application of cost-benefit analysis as the leading method for evaluation of public investments [The Knowledge-Based Economy 1996, p. 27] can be a reliable tool for monitoring the impact of knowledge on the economy.

This perspective appears to have drawn the attention of the Russian authorities and stimulated their decision to invest in knowledge. Being externally directed in terms of the distribution of students around the world, GEP is a part of a much more ambitious plan for the modernization of Russia and its scientific and educational revival. The main 
programme of the Ministry of Education and Science is Russian Academic Excellence more well-known as "5-100-2020" (the aim is for 5 top-Russian universities to be among the top-100 in world university rankings by 2020) to improve the competitiveness of Russian universities by strengthening their positions in the world market [World-Class Russian Education 2015].

The project aims to expand university research capacities and turn them into some of the world's leading scientific centres. In comparison with GEP with its planned implementation of 3 years (2014-2016), "5-100-2020" is an umbrella programme focusing on both internal and international development and setting aspirational goals within a broader timeframe (2013-2020). In the state programme "Development of education for 2013-2020" the specified areas of improvement are:

- the need for highly-qualified personnel in order to contribute to economically underdeveloped areas and enhance technological advancement for the modernisation process;

- the formation of a leading Russian universities group and increasing their positions in world university rankings;

- increasing the effectiveness of youth involvement in policy initiatives in order to facilitate innovative ways of state development [Dmitry Medvedev evaluates Project 5-100 2016].

On 19 April 2016 Prime Minister Dmitry Medvedev highlighted the positive results already achieved in the promotion of Russian universities and faculties in top-100 ratings and the entrance into the global rankings for the first time by Moscow Institute of Physics and Technology. He stated that government aid would continue to support universities pursuing improvement in their competitive standing, pointing to research activities as a core competitive factor [Dmitry Medvedev Evaluates 2016]. The subsidies for "5-100-2020" constitute more than 10 billion rubles [Dmitry Medvedev evaluates project 5-100 2016] - more than twice as much as 4,41 billion rubles initially planned for the GEP implementation taking into account that the timeframe for 5-100-2020 is more than twice as long .

However, the Russian government policy initiatives are not unique. The European commission report 'Composite Indicator for Scientific and Technological Research Excellence', its rationale and components highlight the growing policy-based interest in research excellence [Sørensen, Bloch, Young 2015] drawing attention to the shift from peer review forms of assessment to the necessity to produce breakthrough knowledge, forecast and control tendencies as the key elements of success in a knowledge-based economy. As the report states, the EU 2020 strategy contains a blueprint for transforming Europe into an 'Innovation Union' by 2020. The targets are "to boost cooperation between industry and universities, to ensure the modernization of framework conditions for enterprises, to enhance cross-border cooperation and to embrace joint programming" [Vertesy, Tarantola 2012, p. 6]. Moreover, Vertesy \& Tarantola emphasize that European authorities are planning to take control over "the increase towards a more knowledgeintensive economy in Europe" [Vertesy, Tarantola 2012, p. 6]. Taking into account the significant number of European universities in the world rankings, more advanced and flexible economies, which to not depend on external factors (e.g. fluctuations in raw materials prices and currency) and the stable educational systems based on linking traditions and innovations, the Russian targets appear to be extremely ambitious requiring a large investment of resources, time and money. 
Jöns \& Hoyler [Jöns, Hoyler 2013] highlight that "since the first rankings inception in 2003, a decade of increasing internationalization, neoliberalization, and marketization of higher education followed" and "the annually updated league tables have captured the attention of university managers, employers, policy makers, academics and the wider public" [Teichler 2004; Lynch 2006; Sadlak, Liu 2007; Hazelkorn, 2011 cited in Jöns, Hoyler 2013, p. 45]. Although Jöns \& Hoyler critique the prioritizing of rankings of resource-intensive technosciences conveying a limited sense of scholarship, they emphasize the scale of their influential power on educational policies [Jöns, Hoyler 2013]. The Russian government pursues a place on the world stage and the target of GEP 0 and "5-100-2020" policies to engage the above-mentioned stakeholders into mutually beneficial long-term cooperation can be a clear illustration of this.

From Jöns \& Hoyler's point of view and Medvedev's statement, the research impact factor was emphasized by the rating agency RAEX in 2015. Three integral factors determining rankings pointed out by the ranking agency are as follows [Rejting vuzov Rossii 2015]:

- the conditions which provide quality education (50\%)

- future employment rates $(30 \%)$

- the level of research (20\%) (10\% scientific achievement, $6 \%$ innovation activity and $4 \%$ innovation infrastructure).

The third factor (level of research) correlates positively with the policy objectives, but the extremely broad umbrella factor (conditions of providing quality education) which is seen as the driving force determining the aptitude of a country to compete in the international arena, does not. Serious methodological limitations of rankings are highlighted in the research as they "are being used for a broader range of purposes than originally intended and [... are] bestowed with more meaning than the data alone may bear" [Counting What Is Measured or Measuring What Counts 2008, p. 7, cited in Jöns, Hoyler 2013, p. 46]. This emphasizes the power of accountability as a reliable instrument which can be elaborated on with a certain amount of systemic control.

Experts from the Centre of Economic Development and Certification of The Institute of Economic Strategies (CEDCIES) of The Russian Academy of Sciences critically evaluate the increasing chase for rankings [Programma "5-100" 2016]. They exemplify the subjective features of ranking scales, the noteworthy differences between them, and their striving for brand promotion. The supremacy of brands is also highlighted by Aushev, vice-provost for scientific work and strategic development of Moscow Institute of Physics and Technology, who draws attention to the historically-formed attitude of academics reluctant to simplify their research findings to make them more digestible to the general public and keen to keep their research more confidential because of widespread censorship issues. He draws attention to the competitiveness of science which is no longer limited to research activities [Aushev 2015] - it requires thoughtful and longterm promotional strategies to blend pragmatic scientific discoveries with the attraction of resources from the entire world through the media to facilitate further growth.

Russian universities are not the most famous in the world so the timeframe for " 5 100-2020" (around 8 years) appears optimistic for reaching the desired positions and maintaining them in the future. CEDCIES experts question the efficiency and applicability of the ranking chase to Russian realities with so many graduates currently unemployed and employers searching for proof of skills and relevant work experience not for degrees from prestigious universities which publish extensively and match the ranking criteria. 
They repeat the suggestion of Moscow State University provost Victor Sadovnichiy to create Russia's own rankings which would deal with a wider range of locally pragmatic criteria from living conditions in dormitories to corruption and graduate employment potential [Programma “5-100” 2016].

One significant lower ranking indicator is the decrease in the number of academic staff members per student justified by the legal obligation to increase annual salaries and the lack of the financial resources to handle this challenge. The solution found was to reduce the number of staff members or working hours [Rejting vuzov Rossii 2015]. As a consequence of the lack of funding and the decreasing number of academic staff members the aim of improving the impact factor, publishing activity and citation rates according to foreign scientometric systems can affect the quality of publications negatively. Moscow and Saint-Petersburg universities seriously suffered from this reform. Consequently future full-time mutually beneficial employment of the students of education faculties risks becoming a difficult and bureaucratic issue.

The development of international integration, such as the rapid growth of cooperation with foreign universities and running double-degree programs was identified as the most important higher ranking indicator; successful steps are being made in this direction by the best Russian universities. However, GEP excludes funding double-degree programs, MBA programmes and internships as there are indicators showing high numbers of students involved in these programmes and currently employed in Russia. GEP focuses on the deficiency in the quality of Masters and Ph.D. specialists in five underdeveloped areas. They are the target audience and there is a high probability that they are unable to be self-funded. Centring on this target group GEP aims to fill this gap, therefore participants have to return to Russia and to find related employment until at least 2020.

Table 1. The GEP promotion events in numbers (2014-2016) ${ }^{1}$

\begin{tabular}{|l|c|}
\hline The number of events & The number of participants \\
\hline 252 educational exhibitions (Consultations and Presentations) & 208559 \\
\hline 321 seminars for candidates and participants & 2765 \\
\hline 171 seminars for partner organisations & 12611 \\
\hline 177 presentations in Russian higher educational institutions & 31330 \\
\hline 24 youth forums & 6920 \\
\hline 108 webinars for candidates and participants & 2407 \\
\hline 24 webinars for partner organisations & Over 5,3 million \\
\hline 160 newsletters & \\
\hline
\end{tabular}

\footnotetext{
1 Presentation by Ksenia Ivanenko, Head of Educational Development Center of Moscow School of Management,
} Skolkovo March 172017. 
Although multi-target employment assistance is provided, it is the partipicant's full responsibility to be employed within three months of graduation, which was defined at the December 2015 conference ${ }^{2}$. This questions the smooth-running process of employment, emphasizing its restrictions and a lack of guarantees given the dependence on external economic factors. Moreover, the currently unstable economy may undermine trust in the state, which can manipulate the statistics of participation. The relatively low reach of the advertising campaign supports this proposition (Table 1).

The continual and thorough monitoring and reassessment of GEP's intermediate outcomes are of crucial significance as competition across the globe is rapidly increasing. Without this there is unpredictability, and the danger of "being late" as there is no being "on time" [Derrida 2000, p. 20; as cited in Hughes-Warrington 2012, p. 319] for becoming a leader in the international arena and for surpassing the successes of the past. As a consequence, bridging the gap between what exists within and beyond the ethical framework, capitalism and social responsibility is a challenging mission for GEP.

\section{Rationale for GEP implementation - mismatches between intention and reality}

The main challenge of the programme is ensuring the process of finding employment is reliable and timely. The current number of employers is $607,36 \%$ of which are located in Moscow and Saint-Petersburg. No more than $10 \%$ can be employed in these cities which means that more than a third of the employers are allowed to provide only $10 \%$ of potential graduates with jobs. Another mismatch may be between the employers' activity and location and the studies chosen by an applicant. $49 \%$ of employers operate plants and factories, $19 \%$ - educational institutions, $19 \%$ - scientific organizations, $11 \%$ - healthcare organizations and 2\% - social sphere organizations (Table 2).

Table 2. Employment Mismatches ${ }^{3}$

\begin{tabular}{|l|c|c|c|c|}
\hline Employers & $\begin{array}{c}\text { Number of employ- } \\
\text { ers, \% }\end{array}$ & $\begin{array}{c}\text { Areas of } \\
\text { improvement }\end{array}$ & $\begin{array}{c}\text { Number of partici- } \\
\text { pants, \% }\end{array}$ & $\begin{array}{c}\text { The difference in } \\
\text { percentage }\end{array}$ \\
\hline Plants and factories & 49 & Engineering & 36 & 13 \\
\hline $\begin{array}{l}\text { Educational } \\
\text { institutions }\end{array}$ & 19 & Education & 13 & 6 \\
\hline $\begin{array}{l}\text { Scientific } \\
\text { organisations }\end{array}$ & 19 & Science & 27 & -8 \\
\hline $\begin{array}{l}\text { Healthcare } \\
\text { organisations }\end{array}$ & 11 & Health care & 10 & -12 \\
\hline $\begin{array}{l}\text { Social sphere } \\
\text { organisations }\end{array}$ & 2 & $\begin{array}{c}\text { Management in the } \\
\text { social sphere }\end{array}$ & 14 & 1 \\
\hline
\end{tabular}

\footnotetext{
2 http://educationglobal.ru/en/

3 Presentation, December 112015.
} 
Some areas of concern for preventing a misbalance are featured in Table 2. If the percentage of the number of participants is higher than the percentage of legitimate employers, it shows a restriction in employment opportunities and competition between the participants. The difference is very significant in the social sphere and in science. Other issues include potential relocation challenges, employers' prestige, pay rates and HR policy, the number of positions available, labour conditions and rules. If these numbers are not balanced, there is the danger of graduate dissatisfaction, extensive bureaucracy for the programme operator aimed at satisfying the graduates and, the real danger, a failure to find a suitable employer. Moreover, employers in areas in need may not benefit from collaboration with participants if they are located in remote areas or they are in a stage of development unattractive to employees, they cannot offer a competitive salary.

The mismatch between the international curriculum and future work responsibilities has to be taken into account as well. Unlike management, human relations or public relations, where international experiences are quickly absorbed by Russia, the areas of, for example, social work or education can be significantly different as they tend to be focused on internal achievements. In contrast, European universities prefer to focus on both local and international experiences, which are not necessarily applicable to the Russian environment and ethos. Foreign educational experiences may appear irrelevant to a certain extent and a number of new skills might need to be gained at the workplace.

Employability is understood as 'work-readiness'. The factors enabling new graduates to make productive contributions to organizational objectives after commencing employment are:

- the possession of suitable skills

- knowledge

- attitudes

- commercial understanding

Being over-qualified and under-experienced can be a problem especially for $\mathrm{PhD}$ students who constitute $20 \%$ of GEP participants. $\mathrm{PhD}$ graduate with internationallyrenowned degrees tend to be more ambitious in pursuing more responsibility, the prestige of a more senior position and a higher salary as a consequence. In contrast, employers see this negotiation from a different perspective as "structured work experience is more likely to have positive effects on graduates' employment prospects than is the case for university departments' efforts to develop employability skills in classroom settings" [First Joint Special Report of the Business 2015, p. 12].

However, an important attenuating circumstance is that flexibility and transitioning between the areas are not forbidden, for example IT specialists can be employed in educational and medical institutions and education specialists work in factories and social sphere organizations. These transitions can be of great help, but may be timeconsuming and restrict personal preferences.

\section{GEP geographies and the cultural context: comprehension and diversity or one more challenge?}

In contrast to the political context featuring challenges and a number of uncertainties, the cultural context of the GEP appears to promise more diverse trajectories for the 
participants. The main advantages of the programme are the cultural aspects which have a great potential to provide a broad range of invaluable educational and personal experiences. The potential to unite the diversity by respecting every single member makes the programme applicant-friendly.

Membership in alumni clubs of top-world universities is one of GEP's cultural advantages. It is of particular importance for the participants in the field of education, as it has a huge potential to enhance collaboration in terms of, for example creating of joint programmes, organizing conferences, inviting expert guest speakers and benefiting from "glocalisation".

Regarding the idea of cultural diversity in international campuses, Barton criticizes the referral of international students as a 'cohesive entity', emphasizing "the wide variety of countries, ethnicities, and cultures they belong to, their distinct individual needs, and the variety of reasons for studying abroad" [Barton, Hartwig, Cain 2015, pp. 149-150]. Madge, Raghuram, Noxolo suggest broadening the borders of the literal meaning of international students and places them within wider temporal and special contexts:

Individually, international students can be understood within longer-term academic careers [... . Collectively, international student mobility can be seen as part of a wide range of historical intellectual movements that have constituted both knowledge and 'international space' [Madge, Raghuram, Noxolo 2014, p. 694].

This exemplifies the extent of the complexity which GEP faces including the individual and collective level of the participants' educational, personal, cultural and professional trajectories. Their personal choice of the area of studying, the country and the university and further professional placement has some power to inspire later participants to continue their initiatives and together form an intellectual movement.

The intermediate outcomes of the programme have met the expectations to a large extent ${ }^{4}$. and they demonstrate that students are mostly motivated by the level of research in a particular field more than the university ranking. Although it is too early to observe detailed applicant behavioural patterns, there are some tendencies. For instance, Carnegie-Mellon University which is well-known for its excellence in computer science was chosen by 6 IT specialists from Kazan, and Trinity College Dublin, which is famous for its strong solid Humanities tradition, was chosen by 4 educational professionals from the central part of Russia.

The choice of country is often related to the level of economic development, technological advancement, employability and general popularity among international students. UK universities have attracted the highest number of applicants (176) followed by Australia (120), Germany (30), the Netherlands (29) and the US (27). China and Hong Kong (13) are becoming more popular. European countries are mainly represented by Sweden, France, Switzerland, Italy, Spain, Ireland and Belgium [Presentation by Ksenia Ivanenko 2016].

The dominance of English as lingua franca is an extremely relevant issue to the cultural context of GEP, as the vast majority of participants study in English regardless the country. Language variety constantly being narrowed down and is becoming more 
and more monolithic. Robertson points out that "[g]reater academic mobility across Europe is reducing rather than increasing linguistic diversity" and results in "the rapid growth of teaching in English to cope with the linguistic diversity in the classroom" [Robertson 2010, pp. 643-644].

In contrast, other researchers emphasize the "rich potential for the cross-fertilization of ideas" through publications in non-English language journals, translations of books and articles into English, international editorial boards, international conferences in different language contexts and time spent abroad [Helms, Lossau, Oslender 2005, p. 248, cited in Jöns, Hoyler 2013, p. 47]. Jöns \& Hoyler point out that there is "no simple binary division between the hegemonic Anglophone geography and the marginal other-language geographies" highlighting that "both can be occupied simultaneously, are co-constitutive through mutual exchanges and shaped by complex power-relations" [Jöns, Hoyler 2013, p. 47].

Although GEP does not have a language policy and language dominance is not seen as an issue, in December 2015 a number of countries with other official languages (i.e. France and the Netherlands) were advertised as worthy alternatives in order to realize the potential of the programme to capture maximum cultural and linguistic diversity ${ }^{5}$. Moreover, the vast territories of Russia and its borders with different countries have the potential to enhance language exchange diversity which is currently of special priority for "5-100-2020" participants, for example the biggest university in the Far East "the Far East Federal University" is seeking to play a greater role in decentralizing Russian educational hubs.

The cultural aspects of the programme are important mostly for each individual and they vary significantly depending on participants' personal choice and rankings conditions. English language use as a lingua franca is one of the most noticeable cultural issues which simplifies communication and can be an effective means of communication. However, there is a thin line between its dominance over other languages. Collaboration respecting diversity and involving a variety of languages could be of great assistance in balancing the cultural impact.

\section{Intercultural comparisons of the GEP and Fulbright programmes}

GEP with its scale, coverage, and promising diverse cultural experiences is an innovative programme, but several already existing scholarship and cultural exchange programmes, such as Global UGRAD, ERASMUS, BOLASHAK, DAAD Russia and the Fulbright programme could be sources for its inspiration and promotion. Fullbright was established in 1945 and is the longest running programme, serving multiple purposes . Its practice, success and the cultural experiences of its participants could be taken into account and applied to GEP.

Several criteria by which the GEP and the Fulbright programmes may be compared are shown in Table 3.

5 http://educationglobal.ru/en/ 


\section{Table 3. Intercultural Comparisons ${ }^{6}$}

\begin{tabular}{|c|c|c|}
\hline Criteria & The Fulbright programme & GEP \\
\hline $\begin{array}{l}\text { The overall idea } \\
\text { and mission }\end{array}$ & $\begin{array}{l}\text { Cultural exchange and up-skilling, focusing } \\
\text { on individual participants' understanding } \\
\text { of American culture and their professional } \\
\text { benefits }\end{array}$ & $\begin{array}{l}\text { Building highly qualified competitive human } \\
\text { resources to serve the knowledge-based } \\
\text { economy emphasizing a common good for } \\
\text { the future }\end{array}$ \\
\hline $\begin{array}{l}\text { The level } \\
\text { and nature } \\
\text { of the competition }\end{array}$ & $\begin{array}{l}\text { Hidden competition without disclosing the } \\
\text { selection mechanisms }\end{array}$ & $\begin{array}{l}\text { No current competition, only meeting the } \\
\text { basic requirements, possible competition for } \\
\text { employment }\end{array}$ \\
\hline $\begin{array}{l}\text { Policy initiators } \\
\text { and the state } \\
\text { authority } \\
\text { responsible }\end{array}$ & $\begin{array}{l}\text { The Bureau of Educational and Cultural } \\
\text { Affairs [ECA] of the U.S. State Department } \\
\text { under policy guidelines established by the } \\
\text { Fulbright Foreign Scholarship Board [FSB] }\end{array}$ & $\begin{array}{l}\text { Russian president and government, } \\
\text { The Ministry of Education and Science }\end{array}$ \\
\hline $\begin{array}{l}\text { The currency } \\
\text { and the amount } \\
\text { of funding }\end{array}$ & $\begin{array}{l}\text { US dollars } \\
\text { Covers tuition fees and living expenses. } \\
\text { Some funding options for participants' family } \\
\text { members }\end{array}$ & $\begin{array}{l}\text { Russian rubles } \\
\text { The full covering is not guaranteed due to } \\
\text { weak ruble position and currency fluctuations. } \\
\text { Highly dependent on the area of studying and } \\
\text { university of choice }\end{array}$ \\
\hline $\begin{array}{l}\text { Geographies } \\
\text { of the programmes }\end{array}$ & $\begin{array}{l}\text { Exchange of students and professionals } \\
\text { between the USA and countries within the } \\
\text { programme framework }\end{array}$ & $\begin{array}{l}\text { Wide choice of countries limited by university } \\
\text { rankings. Possible widening or narrowing of } \\
\text { geographies due to rankings shifts }\end{array}$ \\
\hline $\begin{array}{l}\text { The actual level } \\
\text { of competition }\end{array}$ & $\begin{array}{l}\text { Highly competitive with a number of options } \\
\text { for postgraduate students, English language } \\
\text { teachers, scientists, university lecturers and } \\
\text { international education administrators }\end{array}$ & $\begin{array}{l}\text { Currently non-competitive with a number of } \\
\text { options which fit within five areas of signif- } \\
\text { icant importance for Russian modernization } \\
\text { and expected increasing competitiveness of } \\
\text { Russian universities }\end{array}$ \\
\hline $\begin{array}{l}\text { The participants' } \\
\text { trajectories }\end{array}$ & $\begin{array}{l}\text { Brain drain prevention due to J-1 US visa } \\
\text { restrictions, meaning participants must return } \\
\text { home. } \\
\text { Mainly focused on individual cultural expe- } \\
\text { riences and work-integrated learning. More } \\
\text { freedom in further knowledge application. }\end{array}$ & $\begin{array}{l}\text { Brain drain prevention due to the contract } \\
\text { obliging participants to return and work for } \\
\text { minimum } 3 \text { years. Mainly focused on gaining } \\
\text { innovative world-class research methodolo- } \\
\text { gies and their application to five "underdevel- } \\
\text { oped" areas. }\end{array}$ \\
\hline $\begin{array}{l}\text { The impact, } \\
\text { prospects } \\
\text { and longevity }\end{array}$ & $\begin{array}{l}71 \text { years of enriching professional and aca- } \\
\text { demic experiences of approximately } \\
279,500 \text { participants. Future potential of } \\
\text { growing and widening geographies. }\end{array}$ & $\begin{array}{l}\text { Less than } 3 \text { years. Intermediate outcomes } \\
\text { feature some inconsistencies and challenges } \\
\text { mainly due to the unpredictability of par- } \\
\text { ticipant choice, their high career ambitions, } \\
\text { currency fluctuations and their implications } \\
\text { on participant's quality of living and academic } \\
\text { outcomes. }\end{array}$ \\
\hline
\end{tabular}

The Fulbright programme serves individual goals to a large extent while pursuing the long-term target of benefiting America's image, culture and society. GEP looks more narrowly economic and coercive, because of Russia's authoritarian style of modernisation. Despite a significant number of differences there is a strong positive correlation between the restrictions and actual missions of both programmes. They offer funding, assistance and incentives only to the point where a participant can succeed in implementing the programmes' objectives. The most hazardous risk is brain drain which the not in the interests of these programmes. That is why it is severely financially

6 http://www.fulbright.ru/ 
punished by GEP. While looking promising to its participants, GEP is a clever human resource investment programme which emphasizes common good against individual trajectories in order to reach long-term economic goals within the framework of the governmental modernization plan.

\section{Participants views on GEP}

26 GEP participants, aged from 23 to 40, took part in an anonymous 10-question online survey using SurveyMonkey. 54\% of the respondents are employed full-time in Russia after finishing their studies, while $46 \%$ of them are either studying or looking for work. The questions are largely about programme development in order to make it more participant-friendly and beneficial to employers; the participants' experiences of applying their professional skills at their current workplaces; advantages and limitations of chasing rankings; and the intermediate outcomes of the GEP and "5-100-2020" programmes.

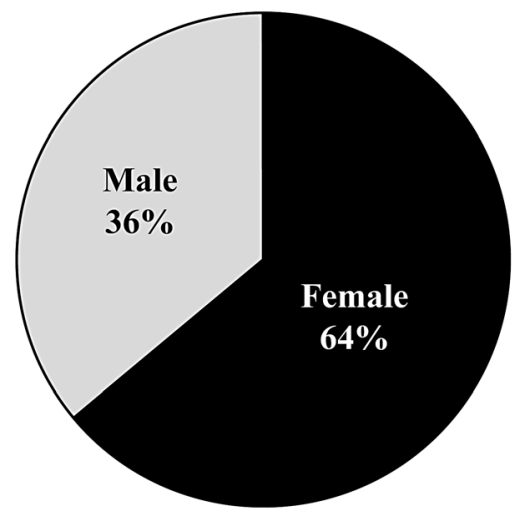

Figure 1. Gender of 25 respondents

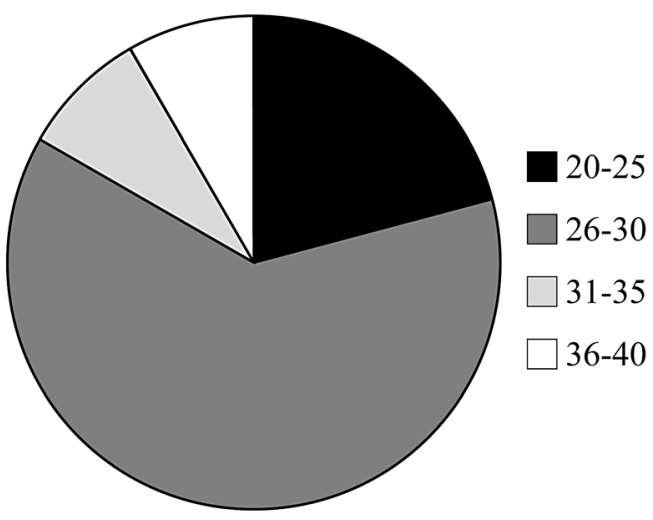

Figure 2. Age of 25 respondents

20 respondents pointed out that conditions of employment should be reconsidered. Areas for improvement include:

- the opportunity to work in state bodies

- the exclusion of the public policy strand from the list of 5 priority areas due to the extremely limited number of employers

- preparatory measures (participants should know in which companies they are going to be employed before returning)

- assistance in employment according to the awarded degree, individual plans of employment

- prolonging the time limit (at least 6 months, preferably a year instead of the current 3 months) 
- the cancellation of the fine or the obligation to pay only the amount of the grant in case of any violations

- the cancellation of the fixed list of employers or substantial simplification of the inclusion into it ("There is no need in the approval of the relevant ministries and the Supervisory Board if the company meets the GEP criteria")

- increasing the quota for the capitals (Moscow and Saint-Petersburg) in proportion to the number of vacancies in these regions (if $50 \%$ of the companies listed are based in Moscow, 50\% of the participants should be eligible to work in Moscow)

- the need for the research into the employment mechanism and further support for young specialists in remote areas

- An increase of employers' interest in the programme (2 participants were rejected just because the procedure for inclusion in the employer list was unclear

The majority of the respondents express interest in addressing complex issues, the most frequently mentioned of which are the clarification of the employment quotas and the extension of the employer list. These proposals indicate that employment-related mismatches are causing competition. Financial stability, professional fulfilment and appropriate living conditions are the basics which participants strive for. However, the survey reveals that they often have to meet formal GEP requirements which can be in conflict with the humanistic aim of social support of high academic achievers. Other suggestions include funding in the currency of the country of study, funding equal to $100 \%$ of tuition fees plus associated costs in order to decrease difficulties arising from exchange-rate fluctuations, and reducing bureaucracy. All of the respondents are confident that these issues should be discussed at regular meetings of the Supervisory Board.

Answers to "How do you apply the skills acquired abroad in the workplace?" shows the employment concerns. They indicate the variety of participants' experiences ranging from the limited work opportunities and potential to fulfil career ambitions (all such answers look similar and describe the issue of quotas for Moscow and Saint-Petersburg, low payments, bureaucracy and time restrictions) to a much greater contentment with the educational and professional paths chosen. These are some of the positives views:

"The application of the international experience to Russian business".

"Trying to introduce a more progressive attitude to international students, conduct activities to attract greater numbers to the university".

"After graduation I plan to continue working in science in Russia, which will be a natural extension my studies".

"After graduating from a British university, I began to think critically. In this regard, I am able to analyse large amounts of information a lot better".

"If employment conditions allow me to get hired by a desirable company, the skills learned will be $100 \%$ applicable".

Figure 3 demonstrates the participants' priorities of having internationally recognized degrees.

The dominance of the quality markers of education over more commonplace ones such as simply having a degree and membership in alumni clubs can be clearly observed. These reflect the discussion of employment issues: while the true indicator of a quality education guaranteed by a rigorous assessment is the core component of studying abroad, the brand power featured in the prestige option also appeals to 
the participants. In addition, $19 \%$ of the respondents pointed out "other" priorities, including the in-depth study of the previous studies, the opportunity to look at your specialty from the perspective of the practice of another state and, in the future, compare it with the Russian practice, and the opportunity to understand the theory more thoroughly. The opportunity to learn from the best specialists in the professional field, useful professional acquaintances and networking are worthwhile were also mentioned.

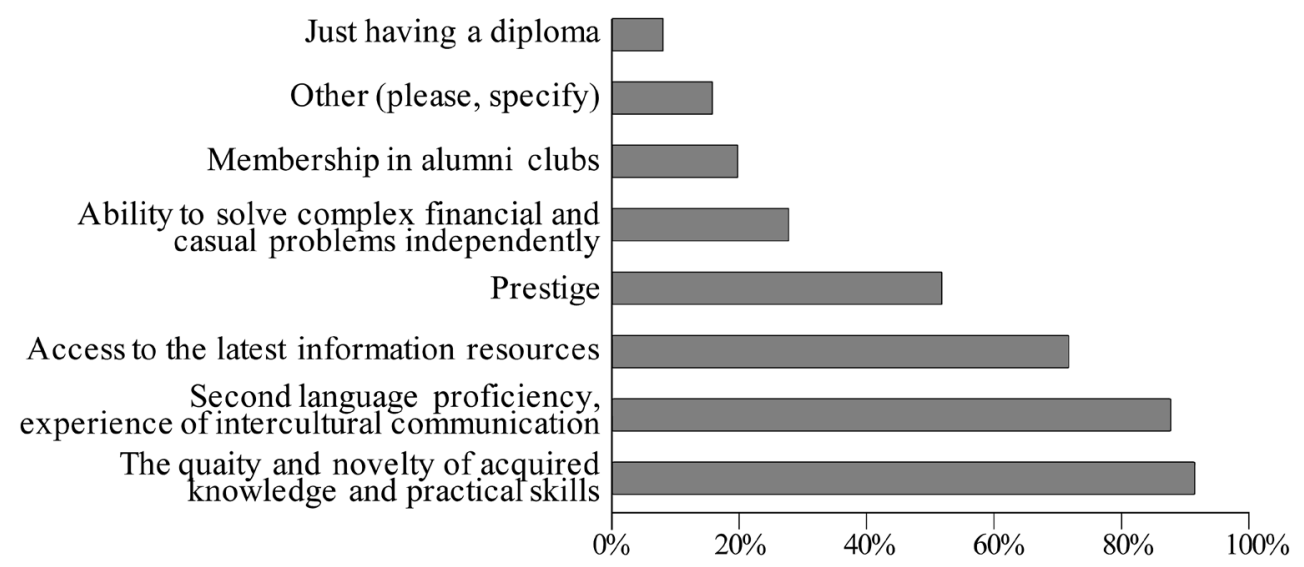

Figure 3. Participants' priorities

Answers to "What changes, in your opinion, should be introduced to Russian Universities with the aim of improving the quality of higher education, its popularity with Russian and international students and guaranteeing higher position in the most prestigious world rankings?" can be divided into four broad issues: controversially perceived chasing rankings, a lack of advancement in teaching methodology, financial and organizational imperfections and relatively poor conditions for effective learning process. Table 4 features the percentage of the respondents indicating these areas of improvement.

Although financial and organizational imperfections are more extensively commented on, a certain interrelatedness in the diverse opinions of respondents can be observed. They are eager to see Russian universities match the speed of innovations in education and science while transforming educational process from more conservative "teacher and textbooks" methods into more collaborative and researched based work. Better conditions to facilitate learning are recommended along with providing financial and methodological resources for teachers to keep pace with the times and invest their time in professional development instead of paper work. The power of rankings themselves and indicators required by them are the most controversial issue. While the majority support the striving for higher rankings, a smaller proportion of them oppose this, highlighting that the quality of education and rankings are not interrelated to a great extent and the resources are not sensibly invested. 


\section{Table 4. Four GEP issues}

\begin{tabular}{|c|c|c|}
\hline The issues & The commentaries & $\%$ \\
\hline $\begin{array}{l}\text { Chasing } \\
\text { rankings }\end{array}$ & $\begin{array}{l}\text { "I am very critical of " } 5-100-2020 \text { " programme. The fact that the universities simply match } \\
\text { the indicators does not lead to the improvement of the educational system and its prestige } \\
\text { overall." } \\
\text { "Improving positions in the rankings requires a high index of citation. I do not think that it is } \\
\text { exactly what Russian universities need as we have a lot of "internal' challenges." } \\
\text { "Rankings are calculated by European or American organizations according to certain crite- } \\
\text { ria. The position in the ranking is not an indicator of quality." }\end{array}$ & 28 \\
\hline $\begin{array}{l}\text { A lack of } \\
\text { advance- } \\
\text { ment in } \\
\text { teaching } \\
\text { methodology }\end{array}$ & $\begin{array}{l}\text { "Teachers should give answers and clarification instead of referring to self-study." } \\
\text { "There is a need to develop mentoring and tutoring as part of educational work." } \\
\text { "More teacher interest in feedback from students." } \\
\text { "New methods - group work, peer teaching/learning." } \\
\text { "English language should be compulsory." } \\
\text { "More guidance on the latest research articles instead of textbooks." } \\
\text { "Stricter punishment for plagiarism and encouraging more learner autonomy." }\end{array}$ & 38 \\
\hline $\begin{array}{l}\text { Financial } \\
\text { and orga- } \\
\text { nizational } \\
\text { imperfec- } \\
\text { tions }\end{array}$ & $\begin{array}{l}\text { "Visiting professors have to lecture for longer time in order to give students chances to get } \\
\text { involved in the subject with a deeper engagement." } \\
\text { "The salaries of the academic staff should correspond to the international level - to enable } \\
\text { them to do research instead of administrative work." } \\
\text { "Significant financial incentives for publications and presentations at international } \\
\text { conferences." } \\
\text { "More cooperation with foreign research centres, joint research and joint article writing." } \\
\text { "The introduction of modular systems with more logic in the sequence of course selection." } \\
\text { "The introduction of a convenient online system tied to personal university student, alumni } \\
\text { and faculty accounts." } \\
\text { "Involvement of young energetic staff." } \\
\text { "Increasing the number of English-language programmes." } \\
\text { "Financial rewards for gifted students." }\end{array}$ & 70 \\
\hline $\begin{array}{l}\text { Poor } \\
\text { conditions } \\
\text { for effective } \\
\text { learning }\end{array}$ & $\begin{array}{l}\text { "Improving the conditions in student residences (creating separate dormitories for interna- } \\
\text { tional students with better conditions and a higher cost of living)". } \\
\text { "Creating a convenient learning environment: upgrading libraries, resource centres and study } \\
\text { rooms". }\end{array}$ & 15 \\
\hline
\end{tabular}

Answers to "For what reasons do Russian universities not hold leading positions in the world rankings?" provided reasons which are very similar to the ones expressed by Aushev [Aushev 2015]. Historical approaches and cultural differences are emphasized. Russian universities are more focused on educational process, while Western ones focus on research. $76 \%$ of the respondents are confident that academic excellence in top Russian universities meets the world standards. However, the integration of science and business is required: technological and research companies should be created on the basis of university output.

Most top level universities are "sharpened" for rankings; their academic staff try to publish in certain journals to increase their own and the university's ranking. This trend has just started to be taken seriously in Russia. Some world-renowned Russian professors publish in low-rated Russian journals, as they are not motivated enough to go through the extremely time-consuming (1-2 years) and rigorous procedure peer review (from the anonymous survey).

More than $50 \%$ of the respondents say that low salaries lead to the brain drain from Russian universities and almost all the academics have to look for additional sources of 
income. $88 \%$ of the participants indicate the poor level of academic English as the main problem. In their opinion, a lack of English mastery leads to fewer English-language programmes, therefore, fewer numbers of international students and teachers. Another consequence is that many of the significant research results are published only in Russian: they are not read abroad which causes low citation indexes.

The last question clarifies whether GEP participants are planning to stay in Russia after 3 years of compulsory employment. All the respondents indicate that they would be pleased to stay and continue working if their positions allow them to apply their skills, provide decent working conditions, career development opportunities and a competitive salary. More than $40 \%$ say that they might leave Russia if better opportunities are offered. The US, Canada, Australia, New Zealand, the UK, the UAE and Singapore are mentioned as the countries of potential interest for GEP participants.

\section{The future of GEP}

According to the document which started the programme [Ukaz prezidenta Rossijskoj Federatsii 2013], the first steps including grants to 718 GEP participants and their temporary leaving Russia for the chosen countries of studying were not implemented to the expected extent. According to data from 8 December 2016, the number of participants was 413 which is slightly less than $58 \%$ of the planned number. The reduction of budget allocations for the completion of GEP is given in the explanatory note to the Federal law project "On the Federal Budget for 2017 and the planned period of 2018 and 2019 years" [Poyasnitel'naya zapiska 2016, pp. 124, 127]. However, a broader timeframe until 2025 was established in March 2017 [Postanovleniye pravitel'stva 2017] which implies that all the participants are supposed to finish their compulsory employment of at least 3 years by 2025 . Another amendment features an increase in the proportion of participants eligible to work in Moscow and Saint-Petersburg from $10 \%$ to $25 \%$ of all the participants which has the potential to make the programme more applicant-friendly and lower violation risks. All the other programme conditions including the size of the grant (a maximum of 2,763,600 roubles), the number of expected participant (718) were not reconsidered at this stage.

\section{Conclusions}

GEP as a policy initiative promises great benefits for Russian authorities, employers, participants, and foreign university staff and students. Its targets are part of "5-100-2020" in the framework of the state programme "The development of education for 20132020 ". GEP may become a powerful force for economic prosperity and the realization of the country's ambitious plans for modernization. However, it is extremely hard to predict its future direction as there are too many local variables and implications of participant choices, and an extremely high level of competition worldwide.

Economic stability has the greatest influence as it is needed to facilitate the decentralization and diversification of the Russian economy. The size of Russia and its 
two main economic clusters in Moscow and Saint-Petersburg, having the largest number of employers, require and restrict decentralization. Likewise, there are ambivalent attitudes to the Anglo-American centred uneven geographies of world higher education, the Moscow and Saint-Petersburg, where best Russian universities are located. However, the status quo has the potential to be "reshaped and widened" by "5-100-2020" and the GEP mission within it.

The cultural context of GEP is an invaluable resource for enriching multilevel diversity and individual experiences. The American and Russian approaches to educational and cultural exchange programmes are motivated by different factors: benefiting America's image worldwide and facilitating the modernization of the Russian economy. Although there are a number of restrictions driven by Russia's authoritarian modernization style, GEP, compared to the Fulbright programme, is more applicantfriendly in terms of competition and promising to facilitate participants' contributions to the common good at the state level while respecting their personal and professional autonomy.

Consistency, logic, continual and thorough monitoring and reassessment can support the bringing home of cutting edge research methodologies and assist in their application in the labour market. Moreover, GEP's potential effectiveness and transparency can be effective ways of creating networks, exchanging knowledge and experience within different levels of international cooperation and preventing brain drain.

\section{References}

Ackers L. (2008) Internationalization, Mobility and Metrics: A New Form of Indirect Discrimination? Minerva, vol. 46, no 4, pp. 411-435. DOI: 10.1007/s11024-008-9110-2.

Aushev T. (2015) Nemaya nauka: pochemu russkie uchenye ne ishchut zhizn' na Marse [Silent Science: Why Do not Russian Scientists Look for Life on Mars]. RBK. Available at: http://www.rbc.ru/ opinions/society/30/09/2015/560bdeb89a7947ee3fa0b4b1, accessed 31 May 2017.

Barton G.M., Hartwig K.A., Cain M. (2015) International Students' Experience of Practicum in Teacher Education. Australian Journal of Teacher Education, vol. 40, no 8, pp. 149-163. DOI: 10.14221/ajte.2015v40n8.9.

Brandenburg U., De Wit H. (2011) The End of Internationalization, International Higher Education. Center for International Higher Education Boston College, vol. 62, Winter, pp. 29-33.

Council Conclusions of 12th May, 2009 on a Strategic Framework for European Cooperation in Education and Training [2009/C 119/02] (2009). The Council of the European Union, Brussels.

Counting What Is Measured or Measuring What Counts? League Tables and Their Impact on Higher Education Institutions in England (2008). Centre for Higher Education Research and Information (CHERI), Open University, and Hobsons Research. Report to HEFCE.

Derrida J. (2000) Of Hospitality: Anne Dufourmantelle Invites Jacques Derrida to Respond, Stanford University Press.

Dmitry Medvedev Evaluates Project 5-100 (2016). The Ministry of Education and Science of the Russian Federation. Available at: http://5top100.com/news/34135/, accessed 31 May 2017.

First Joint Special Report of the Business, Innovation and Skills and Education Committees of Session 2015-16 (2015). Digital Education Resource Archive (DERA). Available at: http://dera.ioe.ac.uk/24710/1/9780215087782.pdf, accessed 31 May 2017.

Fulbright Program in Russia (2016). Fulbright.ru. Available at: http://www.fulbright.ru/, accessed 31 May 2017.

Gosudarstvennaya programma Rossijskoj Federatsii «Razvitie obrazovaniya» na 2013-2020 gody (2013) [State Programme for the Russian Federation ‘Development of Education' for 
2013-2020]. The Ministry of Education and Science of the Russian Federation. Available at: http://xn--80abucjiibhv9a.xn--p1ai/\%D0\%B4\%D0\%BE $\%$ D0\%BA $\%$ D1\%83\%D0\%BC $\%$ D0\%B5\%D0\%BD\%D1\%82\%D1\%8B/3409, accessed 31 May 2017.

Hazelkorn E. (2011) Rankings and the Reshaping of Higher Education: The Battle for World-Class Excellence, Palgrave Macmillan. Basingstoke.

Helms G., Lossau J., Oslender U. (2005) Einfach Sprachlos But Not Simply Speechless: Language(s), Thought and Practice in the Social sciences. Area, vol. 37, no 3, pp. 242-250.

Hénard F., Diamond L., Roseveare D. (2012) Approaches to Internationalization and Their Implications for Strategic Management and Institutional Practice. A Guide for Higher Education Institutions. OECD Higher Education Programme. IMHE, pp. 1-49. Available at: http://www.oecd.org/edu/imhe/Approaches\%20to\%20internationalisation\%20-\%20final\%20 -\%20web.pdf, accessed 31 May 2017.

Hughes-Warrington M. (2012) The Ethics of Internationalisation in Higher Education: Hospitality, Self-presence and "Being Late". Educational Philosophy and Theory, vol. 44, no 3, pp. 312-322. DOI: 10.1111/j.1469-5812.2010.00674.x.

Jiang N., Carpenter V. (2014) A Case Study of Emerging Challenges and Reflections on Internationalization of Higher Education. International Education Studies, vol. 7, no 9, pp. 56-68. DOI: 10.5539/ies.v7n9p56.

Jöns H., Hoyler M. (2013) Global Geographies of Higher Education: The Perspective of World University Rankings. Geoforum, no 46, pp. 45-59. DOI: 10.1016/j.geoforum.2012.12.014.

Kenway, J., Bullen, E., Robb, S. (2004) The Knowledge Economy, the Techno-preneur and the Problematic Future of the University. Policy Futures in Education, vol. 2, no 2, pp. 330-349.

Knight J. (2004) Internationalization Remodeled: Definition, Approaches, and Rationales. Journal of Studies in International Education, vol. 8, no 1, pp. 5-31. DOI: $10.1177 / 1028315303260832$.

Lynch K. (2006) Neo-liberalism and Marketisation: the Implications for Higher Education. European Educational Research Journal, vol. 5, no 1, pp. 1-17.

Madge C., Raghuram P., Noxolo P. (2014) Conceptualizing International Education: From International Student to International Study. Progress in Human Geography, vol. 39, no 6, pp. 681-701. DOI: 10.1177/0309132514526442.

O programme (2015) [On the Programme]. Global Education Program. Available at: http://educationglobal.ru/fileadmin/downloads/Presentation_Program_11dec2015.pdf, accessed 31 May 2017.

Official Documents (2016). Global Education Programme. Available at: http://educationglobal. ru/en/ns/overview/officialdocuments/, accessed 31 May 2017.

Paasi A. (2005) Globalisation, Academic Capitalism, and the Uneven Geographies of International Journal Publishing Spaces. Environment and Planning A, vol. 37, no 5, pp. 769-789.

Postanovleniye pravitel'stva Rossijskoj Federatsii ot 15 marta 2017 № 298 «O vnesenii izmenenij v postanovlenie pravitel'stva Rossijskoj Federatsii ot 20 iyunya 2014 № 568» (2017) [Decree of the Government of the Russian Federation from March 15, 2017 No. 298 "On Amendments to the Resolution of the Government of the Russian Federation from June 20, 2014 No. 568"']. Available at: http://educationglobal.ru/fileadmin/downloads/Resolution Government_N298 15mar2017.pdf, accessed 31 May 2017.

Poyasnitel'naya zāpiska $\overline{\mathrm{k}}$ proektu federal'nogo zakona «O federal'nom byudzhete na 2017 god i na planovyj period 2018 i 2019 godov» (2016) [Explanatory Note to the Federal Law Project "On the Federal Budget for 2017 and the Planned Period 2018 and 2019 Years"]. Konsul 'tant Plus. Available at: http://www.consultant.ru/cons/cgi/online.cgi?req=doc;base $=\mathrm{PRJ} ; \mathrm{n}=152889 \# 0$, accessed 31 May 2017.

Presentation by Ksenia Ivanenko, Head of Educational Development Center of Moscow School of Management Skolkovo (2016). ICEF. Available at: http://www-cdn.icef.com/wp-content/ uploads/seminarprogramme/2016/moscow_prov_ag_ 1600 _Dr.-Ksenia-Ivanenko The-Global-Education-Scholarship-Programme-One-Year-On.pdf, accessed 31 May $201 \overline{7}$.

Programma «5-100»: Rejtingi - ne samotsel'! (2016) [Programme "5-100": Ratings Are Not an End in Themselves!]. Kompetentsii uspekha. Tsentr ekonomicheskogo razvitiya i sertifikatsii [Competence Success. The Center for Economic Development and Certification]. Available at: http://profiok.com/about/news/detail.php?ID=3170\#ixzz4b3Wkvihv, accessed 31 May 2017. 
Quarterly National Accounts (2012). Volume 2012. Issue 2. Organization for Economic Cooperation and Development Publishing, Paris.DOI: 10.1787/qna-v2012-2-40-en. Available at: http://www.keepeek.com/Digital-Asset-Management/oecd/economics/quarterly-nationalaccounts/volume-2012/issue-2 qna-v2012-2-en\#page1, accessed 31 May 2017.

Rejting vuzov Rossii - 2015 g. (2016) [High Education Institutions Rating 2015]. Ekspert RA. Available at: http://www.raexpert.ru/rankings/vuz/vuz 2015/, accessed 31 May 2017.

Robertson S.L. (2010) Critical Response to Special Section: International Academic Mobility. Discourse: Studies in the Cultural Politics of Education, vol. 31, no 5, pp. 641-647. DOI: 10.1080/01596306.2010.516945.

Robertson S.L., Olds K. (2012) World University Rankings: On the New Arts of Governing (quality). The Centre for Globalisation, Education and Societies, University of Bristol, pp. 1-20. Available at: https://susanleerobertson.files.wordpress.com/2012/07/2012robertson-olds-world-university-rankings.pdf, accessed 31 May 2017.

Sadlak S., Liu N.C. (eds.) (2007) The World-Class University and Ranking: Aiming Beyond Status, UNESCO-CEPES, Bucharest.

Saxenian A. (2006) The New Argonauts: Regional Advantage in a Global Economy, Harvard University Press. Cambridge, MA.

Sørensen M.P. Bloch C., Young M. (2015) Excellence in the Knowledge-based Economy: From Scientific to Research Excellence. European Journal of Higher Education, vol. 6, no 3, pp. 217-236. DOI: 10.1080/21568235.2015.1015106

Teichler U. (2004) The Changing Debate on Internationalization of Higher Education. Higher Education, vol. 48, no 1, pp. 5-26.

The Knowledge-Based Economy (1996). Organization for Economic Cooperation and Development. Available at: https://www.oecd.org/sti/sci-tech/1913021.pdf, accessed 31 May 2017.

Ukaz prezidenta Rossijskoj Federatsii ot 28.12.2013 № 967 «O merakh po ukrepleniyu kadrovogo potentsiala Rossijskoj Federatsii» (2013) [The Decree of the President of the Russian Federation of December, 2013 28, 2013 \#967 "Measures to Develop the Human Resource Potential of the Russian Federation"]. Global Education Program. Available at: http://educationglobal.ru/fileadmin/downloads/1_УКАЗ_Президента.pdf, accessed 31 May 2017.

Vertesy D., Tarantola S. (2012) Composite Indicators of Research Excellence. European Commission. Joint Research Centre. Publications. Available at: http://publications.jrc.ec.europa.eu/repository/bitstream/JRC72592/reqno_jrc72592 deliverable3_res_exc.pdf(1).pdf, accessed 31 May 2017.

World-Class Russian Education (2015). The Ministry of Education and Science of the Russian Federation. Available at: http://5top100.com/about/, accessed 31 May 2017. 


\title{
Программа «Глобальное образование» в эпоху экономики знаний: контекст и результаты
}

\author{
М.Л. КОВАЛЕНКО*
}

\begin{abstract}
*Марина Леонидовна Коваленко - старший преподаватель, кафедра английского языка для гуманитарных дисциплин, Национальный исследовательский университет «Высшая школа экономики». Адрес: 123022, Москва, Большой Трехсвятительский пер., 3. E-mail: mkovalenko@hse.ru
\end{abstract}

Цитирование: Kovalenko M. (2017) The Global Education Programme in the Era of the Knowledge Based Economy: Context and Implications. Mir Rossii, vol. 26, no 3, pp. 117-141. DOI: $10.17323 / 1811-038 X-2017-26-3-117-141$

Программа «Глобальное образование» («ГО») - это инновационная программа государственного финансирования магистерских и докторских образовательных программ, предлагающая российским гражданам возможность учиться на дневном отделении в ведущих зарубежных высших учебных заведениях, а затем быть трудоустроенными в соответствии с полученной квалификацией в России в течение как минимум трех лет. Программа направлена на сохранение и приумножение высококвалифицированных кадров в области науки, образования, инженерии, медицины и управления в социальной сфере в соответствии с приоритетами российской экономики. Она ориентирована на сотрудничество с ведущими работодателями страны, в том числе с зарегистрированными на территориях опережающего социально-экономического развития на Дальнем Востоке и в Восточной Сибири. «ГО» одновременно представляет собой программу усиления кадрового потенциала страны наряду с социальной поддержкой населения.

Необходимо подчеркнуть, что в настоящий момент в реализации программы «ГО» существуют определенные трудности, среди которых:

- неожиданное отсутствие конкуренции между участниками;

- относительно низкий охват рекламной кампании;

- проблемы нехватки финансирования из-за колебаний валютных курсов и роста цен;

- несоответствие между международными учебными программами и потенциальными трудовыми обязанностями;

- несоответствие между спросом на работу в промышленных и образовательных центрах (Москве и Санкт-Петербурге) и сложности трудоустройства на их территориях, ограниченного 10 -процентной квотой;

- потенциальный риск «утечки мозгов» и чрезвычайная зависимость от экономического положения в России в будущем.

Популярное в развитых странах стремление к экономике знаний привлекло пристальное внимание российских властей и стимулировало инвестиции в эту область. «ГО» является смежным проектом с гораздо более амбициозным планом научно-образовательного возрождения и модернизации Российской Федерации. Важнейшей программой Министерства образования и науки РФ является Проект «5-100-2020» в рамках государственной программы «Развитие образования на 2013-2020 годы». 
Этот проект направлен на реализацию исследовательского потенциала ведущих российских университетов, повышение конкурентоспособности путем укрепления их позиций на мировом рынке и превращение их в ведущие научные центры мира.

Основная задача «ГО» - обеспечить качество и своевременность процесса трудоустройства. В настоящее время в официальном списке «ГО» 607 работодателей, готовых принять к себе в штат финалистов программы, при этом $36 \%$ потенциальных работодателей находятся в Москве и Санкт-Петербурге, но в этих мегаполисах смогут трудоустроиться не более $25 \%$ участников программы. Еще одно несоответствие обнаруживается в сфере деятельности работодателей, из которых 49\% - заводы и фабрики, 19\% - образовательные учреждения, $19 \%$ научные организации, $11 \%$ - органы здравоохранения и лишь $2 \%$ - организации, относящиеся к социальной сфере.

Если процентное соотношение количества участников превышает процент работодателей из официального списка, на стадии трудоустройства может возникнуть риск конкуренции между участниками: более того, эта разница очень существенна в социальной сфере и довольно заметна в науке. Реальную опасность может представлять и отсутствие возможностей найти желаемого работодателя. Кроме этого, работодатели в регионах не смогут получить выгоду от сотрудничества с финалистами, если они будут не в состоянии предложить конкурентоспособную зарплату или их учреждения расположены на непривлекательных для жизни и работы территориях.

Аспиранты (20\% участников) могут столкнуться с проблемой сверхвысокой квалификации: соискатели со степенью $\mathrm{PhD}$, как правило, более амбициозны и нацелены на престижную должность, они стремятся к более высокому уровню оплаты труда, что может входить в разрез с интересами работодателей. Долгие сроки рассмотрения резюме, несколько этапов собеседования, включающих выполнение заданий, огромная конкуренция (особенно для соискателей с узкой специализацией) и ограниченное количество вакансий - это те сложности, с которыми финалистам «ГО» придется столкнуться по возвращении в РФ. Следует также отметить, что условие самостоятельного поиска работы участниками, а не работодателями существенно ограничивает эффективность программы.

В анонимном опросе на платформе SurveyMonkey приняли участие 26 финалистов «ГО» в возрасте от 23 до 40 лет. Было выявлено, что 54\% респондентов завершили обучение и трудоустроены на полную ставку в России, в то время как $46 \%$ либо еще учатся, либо находятся в процессе поиска работы. Темами дискуссии опроса стали развитие программы, взаимодействие с работодателями, возможности применения профессиональных навыков на рабочем месте и анализ промежуточных результатов программ «ГО» и «5-100-2020».

Большинство респондентов выразили заинтересованность в решении таких вопросов, как квотирование рабочих мест на Москву и Санкт-Петербург, необходимость расширения списка работодателей и финансирования в валюте страны обучения, финансирование в размере $100 \%$ оплаты обучения вместе с сопутствующими расходами в целях уменьшения чрезмерной зависимости от колебаний курсов валют. Качество и новизна приобретенных знаний и практических навыков наряду с высоким уровнем владения академическим английским языком были указаны абсолютным большинством финалистов в качестве основных приоритетов обучения в лучших вузах мира. 
В обсуждении были затронуты различные подходы в России и в западных странах к развитию высшего образования, а также культурные различия. В ответах назывались четыре основные проблемы: вопрос чрезмерной ориентированности на рейтинги (низкий уровень академического английского языка считается главным препятствием, ведущим к низкому уровню цитируемости, ограничивающему продвижение в рейтингах), недостаточный уровень прогрессивности в методологии обучения, ограниченное финансирование, влияющее на эффективность организации учебного процесса, и несовершенство образовательной инфраструктуры.

По результатам опроса было выявлено, что $100 \%$ респондентов изъявили желание продолжить работать в России после трех лет обязательной трудовой деятельности согласно условиям программы, если работодатели смогут гарантировать применение навыков, достойные условия работы, карьерный рост и конкурентную заработную плату. Более $40 \%$ допустили возможность эмиграции в случае, если им будут предложены многообещающие перспективы: среди стран, представляющих потенциальный интерес для финалистов «ГО», были названы США, Канада, Австралия, Новая Зеландия, Великобритания, Объединенные Арабские Эмираты и Сингапур.

В период с 2014 по 2016 г. в «ГО» должны были принять участие 718 участников, однако это не было реализовано: согласно данным на 8 декабря 2016 г., гранты получили только 413 граждан РФ. Тем не менее в марте 2017 г. программа была продлена до 2025 г., и процентное соотношение финалистов, трудоустроенных в Москве и Санкт-Петербурге, увеличилось с 10 до 25\% от всех участников. Остальные условия программы, включая сумму гранта (максимум 2763600 руб.), число ожидаемых финалистов (718) и т.д., на этом этапе пересмотрены не были.

Ключевые слова: «Глобальное образование», экономика знаний, интернационализация, инициатива в области образовательной политики, политический контекст, культурный контекст

\section{Литература}

Аушев Т. (2015) Немая наука: почему русские ученые не ищут жизнь на Марсе? // РБК // http://www.rbc.ru/opinions/society/30/09/2015/560bdeb89a7947ee3fa0b4b1

Государственная программа Российской Федерации «Развитие образования» на 2013-2020 годы (2013) // Министерство образования и науки Российской Федерации // http://xn--80abucjiibhv9a.xn--p1ai/\%D0\%B4\%D0\%BE\%D0\%BA\%D1\%83\%D0\%BC\% D0\%B5\%D0\%BD $\%$ D1\%82\%D1\%8B/3409

Дмитрий Медведев оценил реализацию Проекта 5-100 (2016) // Министерство образования и науки Российской Федерации // http://5top100.ru/news/33983/?sphrase_id=6932

Нормативные документы по программе (2016) // Государственная программа «Глобальное образование» // http://educationglobal.ru/ns/overview/officialdocuments/

O программе (2015) // Государственная программа «Глобальное образование» // http://educationglobal.ru/fileadmin/downloads/Presentation_Program_11dec2015.pdf

Постановление правительства Российской Федерации «О внесении изменений в постановление правительства Российской Федерации от 20 июня 2014 №568» (2017) // http://educationglobal.ru/fileadmin/downloads/Resolution Government_N298_15mar2017.pdf 
Пояснительная записка к проекту федерального закона «О федеральном бюджете на 2017 год и на плановый период 2018 и 2019 годов» (2016) // Консультант Плюс // http://www.consultant.ru/cons/cgi/online.cgi?req $=$ doc;base $=$ PRJ;n=152889 $\# 0$

Программа «5-100»: Рейтинги - не самоцель! (2016) // Компетенции успеха. Центр экономического развития и сертификации // http://profiok.com/about/news/ detail.php?ID=3170\#ixzz4b3Wkvihv

Программа Фулбрайта в России (2016) // Fulbright.ru // http://www.fulbright.ru/ru

Рейтинг вузов России - 2015 г. (2015) // Эксперт PA // http://www.raexpert.ru/rankings/vuz/vuz 2015/

Российское образование мирового класса (2015) // Министерство образования и науки Российской Федерации // http://5top100.ru/about/more-about/

Указ президента Российской Федерации от 28.12.2013 № 967 «О мерах по укреплению кадрового потенциала Российской Федерации» (2013) // Государственная программа «Глобальное образование» // http://educationglobal.ru/fileadmin/downloads/1_УКАЗ Президента.pdf

Ackers L. (2008) Internationalization, Mobility and Metrics: A New Form of Indirect Discrimination? // Minerva, vol. 46, no 4, pp. 411-435. DOI: 10.1007/s11024-008-9110-2.

Barton G.M., Hartwig K.A., Cain M. (2015) International Students' Experience of Practicum in Teacher Education // Australian Journal of Teacher Education, vol. 40, no 8, pp. 149-163. DOI: 10.14221/ajte.2015v40n8.9.

Brandenburg, U., De Wit, H. (2011) The end of internationalization, International Higher Education // Center for International Higher Education Boston College, vol. 62, winter, pp. 29-33.

Council Conclusions of 12th May, 2009 on a Strategic Framework for European Cooperation in Education and Training [2009/C 119/02] (2009) // The Council of the European Union, Brussels.

Counting What Is Measured or Measuring What Counts? League Tables and Their Impact on Higher Education Institutions in England (2008). Centre for Higher Education Research and Information (CHERI), Open University, and Hobsons Research. Report to HEFCE.

Derrida J. (2000) Of Hospitality: Anne Dufourmantelle invites Jacques Derrida to Respond, Stanford University Press.

First Joint Special Report of the Business, Innovation and Skills and Education Committees of Session 2015-16 (2015) // Digital Education Resource Archive (DERA) // http://dera.ioe.ac.uk/24710/1/9780215087782.pdf

Hazelkorn E. (2011) Rankings and the Reshaping of Higher Education: The Battle for World-Class Excellence, Palgrave Macmillan. Basingstoke.

Helms G., Lossau J., Oslender U. (2005) Einfach Sprachlos But Not Simply Speechless: Language(s), Thought and Practice in the Social Sciences // Area, vol. 37, no 3, pp. 242-250.

Hénard F., Diamond L., Roseveare D. (2012) Approaches to Internationalization and Their Implications for Strategic Management and Institutional Practice. A Guide for Higher Education Institutions // OECD Higher Education Programme. IMHE // http://www.oecd.org/edu/imhe/Approaches \%20to\%20internationalisation $\% 20-\% 20$ final\%20-\%20web.pdf

Hughes-Warrington M. (2012) The Ethics of Internationalisation in Higher Education: Hospitality, Self-presence and "Being Late" // Educational Philosophy and Theory, vol. 44, no 3, pp. 312-322. DOI: 10.1111/j.1469-5812.2010.00674.x.

Jiang N., Carpenter V. (2014) A Case Study of Emerging Challenges and Reflections on Internationalization of Higher Education // International Education Studies, vol. 7, no 9, pp. 56-68. DOI: 10.5539/ies.v7n9p56.

Jöns H., Hoyler M. (2013) Global Geographies of Higher Education: The Perspective of World University Rankings // Geoforum, no 46, pp. 45-59. DOI: 10.1016/j.geoforum.2012.12.014.

Kenway J., Bullen E., Robb S. (2004) The Knowledge Economy, the Techno-preneur and the Problematic Future of the University // Policy Futures in Education, vol. 2, no 2, pp. 330-349.

Knight J. (2004) Internationalization Remodeled: Definition, Approaches, and Rationales // Journal of Studies in International Education, vol. 8, no 1, pp. 5-31. DOI: $10.1177 / 1028315303260832$.

Lynch K. (2006) Neo-liberalism and Marketisation: the Implications for Higher Education // European Educational Research Journal, vol. 5, no 1, pp. 1-17. 
Madge C., Raghuram P., Noxolo P. (2014) Conceptualizing International Education: From International Student to International Study // Progress in Human Geography, vol. 39, no 6, pp. 681-701. DOI: 10.1177/0309132514526442.

Paasi A. (2005) Globalisation, Academic Capitalism, and the Uneven Geographies of International Journal Publishing Spaces // Environment and Planning A, vol. 37, no 5, pp. 769-789.

Presentation by Ksenia Ivanenko, Head of Educational Development Center of Moscow School of Management Skolkovo (2016) // ICEF // http://www-cdn.icef.com/wp-content/ uploads/seminarprogramme/2016/moscow_prov_ag 1600 Dr.-Ksenia-Ivanenko The-Global-Education-Scholarship-Programme-One-Year-On.pdf

Quarterly National Accounts (2012). Volume 2012. Issue 2 // Organization for Economic Cooperation and Development Publishing, Paris.DOI: 10.1787/qna-v2012-2-40-en // http://www.keepeek.com/Digital-Asset-Management/oecd/economics/ quarterly-national-accounts/volume-2012/issue-2_qna-v2012-2-en\#page1

Robertson S.L. (2010) Critical Response to Special Section: International Academic Mobility // Discourse: Studies in the Cultural Politics of Education, vol. 31, no 5, pp. 641-647. DOI: $10.1080 / 01596306.2010 .516945$.

Robertson S.L., Olds K. (2012) World University Rankings: On the New Arts of Governing (quality) // The Centre for Globalisation, Education and Societies, University of Bristol // https://susanleerobertson.files.wordpress.com/2012/07/2012-robertson-olds-worlduniversity-rankings.pdf

Sadlak S., Liu N.C. (eds.) (2007) The World-Class University and Ranking: Aiming Beyond Status. UNESCO-CEPES, Bucharest.

Saxenian A. (2006) The New Argonauts: Regional Advantage in a Global Economy, Harvard University Press, Cambridge, MA.

Sørensen M.P. Bloch C., Young M. (2015) Excellence in the Knowledge-based Economy: From Scientific to Research Excellence // European Journal of Higher Education, vol. 6, no 3 pp. 217-236. DOI: 10.1080/21568235.2015.1015106

Teichler U. (2004) The Changing Debate on Internationalization of Higher Education // Higher Education, vol. 48, no 1, pp. 5-26.

The Knowledge-Based Economy (1996) // Organization for Economic Cooperation and Development // https://www.oecd.org/sti/sci-tech/1913021.pdf

Vertesy D., Tarantola S. (2012) Composite Indicators of Research Excellence // European Commission. Joint Research Centre. Publications // http://publications.jrc.ec.europa.eu/ repository/bitstream/JRC72592/reqno_jrc72592_deliverable3_res_exc.pdf(1).pdf 